\title{
Liberalization and customer behavior in the Portuguese residential retail electricity market
}

\author{
Mohammad Ali Fotouhi Ghazvini $^{\mathrm{a}, *, 1}$, Sergio Ramos ${ }^{\mathrm{a}}$, João Soares ${ }^{\mathrm{a}}$, Rui Castro ${ }^{\mathrm{b}}$, Zita Vale \\ ${ }^{a}$ GECAD, Research Group on Intelligent Engineering and Computing for Advanced Innovation and Development, Polytechnic of Porto (IPP), Rua Dr. António Bernardino de \\ Almeida, 431, 4200-072 Porto, Portugal \\ ${ }^{\mathrm{b}}$ INESC-ID/IST, University of Lisbon, Portugal
}

\section{A R T I C L E I N F O}

\section{Keywords:}

electricity market

Market liberalization

Retailer

Retail market

Wholesale market

\begin{abstract}
A B S T R A C T
The final step that Portugal is taking to reach a fully liberalized electricity market is the deregulation of the retail market by phasing-out regulated electricity prices and reducing the administrative burdens in this area. These attempts are done to promote the entrance of companies into the retailing business and to actively engage the end-users in the market. This analysis shows that despite high consumer switching rates during the 2013-2015 period, the retail market in Portugal is still highly concentrated. The retail rates are also not following the changes in the wholesale market price.
\end{abstract}

\section{Introduction}

Liberalization reform in the electricity sector starts with the privatization of the state-owned electricity monopolies and unbundling the vertically integrated structure (Joskow, 2008). The primary objective of this reform from the economic and regulatory perspective is to sharpen competition in generation and retail, in order to obtain efficient utilization of available resources in the short run and efficient expansion in the long run (Shen and Yang, 2012). Distinctly separated players at generation, distribution, and retailing are considered in the reference model of decentralized electricity markets. In vertically integrated electricity markets, power supply and network services are provided by the same utility as one service (Kuleshov et al., 2012), which contrasts to restructured electricity markets where the network activities and retailing businesses are separated. Vertical integration between generation and retailing is avoided in most of the competitive decentralized electricity market models (Finon and Boroumand, 2011). Liberalization has opened wide opportunities for smaller companies to enter the wholesale electricity market or retailing business.

In many retail electricity markets, in order to introduce competition, the regional monopoly was dismantled and the distribution system operation and retailing business were separated (Kuleshov et al., 2012). In some cases, a Distribution System Operator (DSO) is allowed to engage in retailing businesses. The minimum requirement, in this case, is the separation of accounts for the competitive and monopolistic activities (Kuleshov et al., 2012). All suppliers should have access to the distribution network at regulated non-discriminatory rates (Littlechild, 2006b). Retail competition has the potential to provide several financial and environmental benefits for the customers. In a liberalized retail electricity market, customers may benefit from more structurally diverse services through competition among service providers. Retail competition allows them to select offers that best meet their needs, regarding price and service quality (Joskow, 2008). Liberalization also should promote the integration of distributed renewable energy sources into the grid. In the traditional electricity industry only large producers generated power, but diverse scales of distributed generation (DG) units or retail companies with self-generation can exist in the liberalized retail market (Bae et al., 2014). Despite these potential benefits, the liberalization has not always led to lower prices for all customers (Von Der Fehr and Hansen, 2009).

After opening the retail market, new groups of suppliers emerged in the market. In most countries, independent pure retail companies that focused mainly on marketing entered the retailing business. Most went bankrupt and others have hardly survived because of the volatility in wholesale market prices (Defeuilley, 2009). The operational cost of these companies is composed of the billing cost, costs for marketing and information systems, and the energy acquisition costs at spot market prices in the wholesale market (Finon and Boroumand, 2011). Some tried to diversify their contract types and develop value-added services. All these approaches only helped them gain positions in the market for

\footnotetext{
* Corresponding author.

E-mail address: ma.fotouhi@gmail.com (M.A. Fotouhi Ghazvini).

${ }^{1}$ Current address: Chalmers University of Technology, Sweden.
} 
short periods, because they were quickly adopted by rival companies. Furthermore, liberalization reform in retail electricity market attracted companies from other geographical zones and companies from other industrial sectors, such as oil and gas, to electricity retail business (Defeuilley, 2009).

Portugal is moving forward with the liberalization reforms in the electricity sector, following the same path of other European liberalized retail markets. The retail market has been opened gradually for consumers, starting from customers supplied at high voltages. The Portuguese Energy Services Regulatory Authority (ERSE) will set the quarterly transitory tariffs for domestic customers until the end of 2017 to encourage the transition from the regulated market to the liberalized market (ERSE, 2016; EDPSU, 2016). This policy has led to high customer switching rates from the last resort supplier to the liberalized market suppliers. The switching rate of final customers refers to the number of end-users who decide to change their supplier when the retail services are liberalized. It is a commonly used indicator for the level of buyer commitment in a market (Concettini and Créti, 2013).

Retail market liberalization aims to convert the electricity consumers into active players of the retail market, which search among an array of competitive retail companies for the best offer and switch to their desired company. The competition-restricting regulation and price controls are removed to increase the consumers' options and to encourage the suppliers to offer innovative products. The products offered to customers in a retail electricity market can be hardly differentiated. This situation puts the competition mostly on price and the contract type. The services are differentiated by offering dual fuel contracts, flexible billing, demand response programs, and energy efficiency services.

Retailers shield the end-users from the price volatility risks by making fixed price contracts with them regardless of spot price changes (Finon and Boroumand, 2011). Retailers act as financial and physical intermediaries between the wholesale market and the end-users. They are always exposed to price risk on the market and quantity risk on the demand side, because electricity prices in the market are extremely volatile and loads are unpredictable. Therefore, they have to implement effective strategies to hedge the volume and price risks of the uncertain delivery obligations in the market (Finon and Boroumand, 2011). The most common approaches that the retailers adopt to keep a certain consistency in their return is re-integrating with the generation companies after the unbundling or making long-term bilateral contracts with them. These methods help them to hedge against the energy price volatility (Murray et al., 2013). The risk management strategies that are only based on spot market purchases or bilateral contracts are not reliable or efficient enough to hedge the risks faced by retailers (Defeuilley, 2009). Retailers in electricity markets lack two main functions of retailers in other industries: (1) transmission and distribution of electricity is not under their control and (2) as their product is a homogeneous good, the opportunity for transformation and marketing is limited (Defeuilley, 2009).

The main motivation for retail market liberalization is to benefit customers through efficiency gains, price reductions and improvements in the quality of services (Karahan and Toptas, 2013). This study evaluates the performance of retail electricity market liberalization in Portugal, focusing on prices. Portugal experienced the highest switching rate among the EU member countries in the years 2013-2015. However, there are doubts about the performance of the competitive market going forward. The high switching rates are experienced during the transition period, when the regulator sets quarterly transitory tariffs. Findings of this research will benefit policymakers in Portugal. To the best of our knowledge, no studies have evaluated the liberalization procedure in Portugal, and this study thus contributes to the literature in this area.

The paper is divided into seven sections including this introduction. Section 2 reviews the literature on retail market liberalization experiences in other countries. Several examples of success and failure for the retail market liberalization can be seen. In section 3 , the process of electricity market liberalization in Portugal at the wholesale and retail levels is reviewed. Section 4 introduces the methodologies, indices and data used in this analysis to evaluate retail market liberalization in this case. Findings for the Portuguese retail electricity market are presented and discussed in section 5. Finally, in section 6, the conclusions and the policy implications are derived.

\section{Previous studies}

Generally, the research on retail electricity market benchmarking is limited. Most studies have focused on a particular feature of the liberalized markets (London Economics, 2012).

Opening the retail markets for competition and removing the restrictive regulations was first tested in Norway and then in Britain (Defeuilley, 2009). Later, many countries in the European Union, New Zealand, and several states in the United States and Australia carried out retail electricity market restructuring (Defeuilley, 2009; Kuleshov et al., 2012). Defeuilley (2009) investigated the reasons why liberalization reform was not able to meet expectations. Two issues were identified for this condition: (1) the complexity of the determinants of choice for consumers, and (2) the technological paradigm in the electricity sector. The first issue yields inactivity of many consumers, even when they had apparent interests for switching to another retailer. The second issue limits new entrants' potential for innovation. Von Der Fehr and Hansen (2009) analyzed household and retailer behavior in the Norwegian market, based on price data and market characteristics. The retail market in Norway was opened simultaneously for all customer segments, unlike other EU countries that gradually opened the market. The regulatory framework is believed to be one of the main reasons for success. The continuous and substantial variation of electricity prices between seasons and years has increased the awareness about the prices and has facilitated the price-based competition (Von Der Fehr and Hansen, 2009) (Mirza and Bergland, 2012). found a substantial asymmetry when retailers pass the impact of wholesale market price changes to the retail customers in the Norwegian market. Price increases were transmitted to customers under the variable price contracts more quickly than the price decreases. Mirza and Bergland (2012) proposed that the end consumers should switch to spot price contracts and make use of smart grid technologies if they do not want dominant retailers with market power to rule the market. This strategy will also help them to deal with asymmetric price-setting behavior.

The evolution of retail market competition in the UK residential energy market is described by (Price, 2005), who assessed the extent to which consumers in general and vulnerable households, in particular, have been influenced by liberalization. The findings of this paper show that the expected price increase for vulnerable customers due to tariff re-balancing was not realized.

The Ministry of Economic Development in New Zealand together with a panel of independent experts appointed by the Ministry of Energy and Resources conducted a review on market performance in 2012 (Shen and Yang, 2012). They made several policy recommendations to address the lack of competition in the market. The main barriers to entry and competition in the retail electricity market were diagnosed as the transmission constraints, the absence of the liquid energy hedge market, and the vertical integration of generation companies and retailers (Shen and Yang, 2012). The policy recommendations in the review were to (1) develop the liquid hedge market, (2) allow distribution companies back into retailing business with some restrictions, and (3) provide funding for the promotion of consumer switching (Shen and Yang, 2012).

The success of retail electricity markets is measured by the changes that the liberalization brings about for end-users in term of energy price and their sensitivity to price changes. Nakajima and Hamori (2010) calculated the price elasticity changes in the US electricity market to evaluate whether household sensitivity to retail rate changes is a 
consequence of electricity market restructuring. No statistically significant difference was noted between the states that restructured and those that did not. Retail choice policies were not distinguished as the main cause of the price elasticity differences. Economists with the US Federal Reserve bank, Dallas branch used a dynamic panel approach and a data set of US states in (Swadley and Yücel, 2011) and found that the retail competition lowers the rates when consumer participation is high but raises the rates when it is low. Karahan and Toptas (2013) explored the impact of retail electricity market liberalization in Turkey during the transition period to see if price declines for consumers have been achieved. Using economic and financial indicators, this research showed that liberalization did not lead to expected results. The retail rates were not following the reductions that occurred in wholesale market prices.

The failure of the liberalization process in achieving its objectives can be shown by the high portion of inactive end-users that show no interest in changing suppliers (i.e., markets with low switching rates), difficulty of competition for new entrants against the incumbent company, and the lack of innovation in energy products and services after opening the market for several years. In many countries, the historical suppliers have the highest market shares and the switching rates have remained very low several years after establishing the liberalized retail market. Alternative suppliers also face entry barriers and difficulties to compete with the incumbent companies. The competition in the Russian retail electricity market after passing the transition period to the liberalized market is assessed in (Kuleshov et al., 2012). The findings are compared with the market condition at the beginning of this period. The main indicator used for evaluating the competition degree in this research is the market share of retailers. The social, political and technological barriers to market liberalization in Russia have been studied. Findings show that four years after market opening, the historical suppliers still dominate the market.

Some markets have adopted restrictive policies on incumbent retailers to ensure the survival of new entrants. For instance, the low market entry barriers in Texas attracted many suppliers to enter the market. The "price-to-beat" mechanism in Texas put a floor under the retail price of incumbent companies to avoid undercutting the prices of new entrants in order to allow them to become established. The "price to beat" should be high enough to ensure a modest profit for new entrants and it should be above the production costs (Tierney, 2008). This transition period took place during the first five years after opening the market.

The necessary functions in a competitive retail market are performed based on information collected from different sources, mainly from the consumers. Therefore, efficient information exchange is a critical component of retail competition, and the success of a retail market may depend on the existence of a reliable cyber infrastructure in addition to widespread smart metering (Bae et al., 2014). Smart meters make the consumers more aware of their energy use and able to participate in demand response programs. There exist significant variations among the EU Member States in the deployment of smart metering. It is expected that almost $72 \%$ of European consumers will have a smart meter for electricity by 2020 (European Parliament, 2015). In the EU Member States where the cost-benefit analysis is positive, there is a rollout target of $80 \%$ market penetration by 2020 (European Commission, 2016).

\section{Electricity market liberalization in Portugal}

Liberalization is a broad term. It usually refers to reducing the government regulations and restrictions in the economy, in parallel with providing opportunities for high participation of the private entities. Liberalization of electricity markets is a process that starts with the shift in ownership from public to private hands, followed by restructuring of the companies, and advanced by fundamental and structural changes in the way that the sector operates (Karahan and
Toptas, 2013).

Portugal is currently on track with its privatization efforts in different sectors. It has supported privatization of the state-owned entities since joining EU in 1986, in compliance with the EU directives. Joining the European economic and monetary union has accelerated the privatization activities in Portugal in line with other member countries (Bräuninger, 2013). The outcomes of the liberalization process in each country can be highly variable with similar experiences in other countries (Karahan and Toptas, 2013).

Legal unbundling of the electric transmission network in Portugal ended in 2000, when the high voltage network was separated from the distribution network. Redes Energéticas Nacionais (REN) is the transmission system operator of Portugal (EU, 2014). REN's main shareholders are China State Grid Group, with 25\% and Oman Oil with 15\% (Macauhub News Agency, 2015). EDP Distribuição owns approximately $99 \%$ of the distribution network in mainland Portugal and serves more than 6 million customers as the distribution system operator. Besides the high-voltage $(60 \mathrm{kV})$, medium-voltage (specifically the $30 \mathrm{kV}, 15 \mathrm{kV}$ and $10 \mathrm{kV}$ ) and low-voltage overhead and underground power lines, the distribution network consists of sub-stations, transformer posts, and other necessary equipment. The facilities used for public lighting are also part of the distribution network. EDP is the holding company of several electricity retailing and generation companies and also Portugal's distribution services provider. These individual companies have requirements on separation within the corporate structure. EDP's largest shareholder is China Three Gorges company with $21 \%$ share (Roberts, 2015). The first main shareholders of REN and EDP are Chinese state enterprises.

EDP's distribution activity is regulated by the Portuguese energy services regulatory authority (ERSE). The regulatory authorities have a key role in promoting competition and switching opportunities in electricity markets (ACER/CEER, 2015). These government-independent entities, which have administrative and financial independence, monitor the market to ensure the competitive and adequate functioning of the market (Conejo et al., 2010). ERSE is responsible for regulating the electricity and natural gas sectors in Portugal and fits supervision into its strategic performance. It protects the interests of electricity consumers, particularly the vulnerable customers, with regard to prices, service quality, and access to information and provides a web tool for communication and interaction with different players of the retail market from electricity suppliers to customers (ERSE, 2016). It also provides a billing simulator for customers (ERSE, 0000). ERSE always checks if the suppliers are publishing the offers that they have practiced in the market on their websites, to guarantee the transparency of the information that the suppliers provide for the end-users. The information on the suppliers' websites is also reconciled with the reference prices sent to ERSE (ERSE, 2016).

In July 2007, the Portuguese and Spanish wholesale electricity markets joined together to create the Iberian electricity market, MIBEL (Vagropoulos and Bakirtzis, 2013). MIBEL replaced the former power purchasing agreement (PPA) model. OMIP is the derivatives market operator located in Portugal, and OMIE is the spot market operator located in Spain. The Iberian electricity market splits when the interconnection capacity between the two countries is congested. Thus, the generation and demand in both countries can only participate in their internal market.

The integration into the Iberian Market improved the competition in both countries because the market share of the regional generation companies was reduced in the integrated area in comparison to their regional markets. The integration of the Iberian market has also influenced the competition at the retail side. Although retail markets are usually considered as national or regional markets, the firms participating in a wholesale market have tried to cross the borders and enter the local retail market of the countries connected to the same wholesale market (ERSE, 2016).

The generation of electricity in Portugal is open to competition. In 
practice, however, it operates through remuneration schemes, such as PPAs, guaranteed compensation mechanisms, and feed-in tariffs. The market concentration of the electricity generation is high in Portugal (EU, 2014), and the incumbent company EDP has the highest market share in electricity generation in Portugal (45\% in 2014) (OECD, 2013; EU, 2014). If the transmission capacity between Portugal, Spain, and France increases, the market share of EDP will reduce in Portugal. In 2004, the European Commission decided to prevent the acquisition of GDP (Gás de Portugal), the incumbent gas company in Portugal, by EDP and ENI (an Italian energy company) in order to restrain the dominant position of EDP in the Portuguese electricity wholesale and retail market (Conte et al., 2005).

The process of the liberalizing the electricity and natural gas markets that began in 2000 will be complete when the phasing out of regulated tariffs finishes (ERSE, 2013). The phasing-out of regulated tariffs encourages the end-users to change their retailer and promotes the entrance of new companies into the retail market. In Portugal, the regulated retail tariffs ended at July 1, 2012, for normal low voltage consumers with contracted power equal to or greater than $10.35 \mathrm{kVA}$ and at January 1, 2013, for normal low voltage consumers with contracted power less than $10.35 \mathrm{kVA}$ (ERSE, 2013). It means that the regulated tariffs are no longer available for the new Portuguese electricity and gas consumers from January 1, 2013 (ERSE, 2013). Consumers should find energy suppliers in the market by the end of the transition period and make new contracts with electricity and gas retailers (ERSE, 2013). During the transition period, consumers have the opportunity to compare and evaluate the offers of the electricity and gas suppliers (ERSE, 2013). In Portugal, the electricity retailers offer a fixed-price product to the customers. The price is usually set for one year, but can have different tariffs during a day.

The transition period is for the gradual transfer from the regulated market to the free market. It ended on December 31, 2014, for consumers with contracted power equal to or greater than $10.35 \mathrm{kVA}$ and on December 31, 2017, it ends for consumers with contracted power less than $10.35 \mathrm{kVA}$. The quarterly transitional tariffs are set until the end of 2017 by the ERSE for consumers who are supplied by the last resort supplier (ERSE, 2013; EDPSU, 2016). After the transition period, the consumers should select the retailer from the liberalized market (ERSE, 2013), and the ERSE will no longer set the regulated tariffs (ERSE, 2013). Switching either the retailer or the product has no direct costs for the Portuguese clients. There is an exception for economically vulnerable customers, who will have access to regulated social tariffs (ACER/CEER, 2015). However, the tariffs for accessing the network will still be set by ERSE after this period (ERSE, 2013). The phasing out of the regulated tariffs will cover 5.6 million electricity consumers in continental Portugal (ERSE, 2013). If a retail supplier fails to supply its consumers, the last resort supplier, which is the EDP Serviço Universal in Portugal, will serve its clients.

Most consumers in Portugal have a long established relationship with EDP. They have learned to use the energy service from this incumbent company during the several years of usage. There might be a great willingness to sign contracts with this company after the removal of regulated tariffs.

On-line electricity price simulation tools are provided by the regulators for the end-users to help them in selecting the retail company. Implementing smart metering enables retailers to benefit from possible demand response programs. It also facilitates supplier switching and enables more frequent information on consumption and billing (ACER/ CEER, 2015). The smart metering roll-out is not planned for the coming years in Portugal. Electricity end-users and suppliers can both access to detailed information about energy consumption with the smart metering technologies installed at the end-points of the network. The pilot project of InovCity in the city of Évora, which is led by EDP Distribuição aims to represent the strategy of the company for smart grids. More than 30,000 smart meters and 340 distribution transformer controllers have been installed in Évora (Torres, 2011). Several other mini-pilots were also implemented across the country. Nevertheless, these programs are very limited and cannot respond to the needs of the country in future years.

\section{Data and methodology}

In this paper, we are interested in evaluating the performance of the liberalized retail electricity market in Portugal. Earlier studies on the Portuguese electricity market focused mainly on the competitiveness of the wholesale market (Ferreira et al., 2007). conducted one of the earliest studies on the restructuring process in Portugal's electricity sector. It was carried out before the operation of the free Iberian market (Amorim et al., 2013). assessed the amount of electricity traded without state guaranteed prices and identifies the main challenges facing the transition towards a competitive Portuguese electricity generation market (Crispim et al., 2014). reviewed the role of ERSE in establishing regulations to promote smart grid solutions for the Portuguese electricity market. They concluded that the lack of competition in distribution requires a more active role for ERSE in terms of defining criteria, allocating incentives and measuring compliance. Evaluating the performance of the Portuguese retail electricity market and its potential for transforming into a competitive market have been overlooked in the literature.

The progress in the retail market liberalization can be assessed by several qualitative and quantitative measures introduced in the literature. Each study selects the indicators based on the aspect of the retail market that they want to explore and the available market data (Defeuilley, 2009). used consumers' switching, the evolution of consumers' mobility, the switching costs, the number of new entrants in the retail market and the innovations which successfully passed the market test to evaluate whether the opening of market at the retail side yielded the influx of new entrants stimulating processes and if it has challenged the incumbents.

The annual reports of the Office of Gas and Electricity Markets (Ofgem), the UK government regulator for the electricity, on the performance of the retail electricity market is based on key trends such as the changes to market structure, prices and profits on the supply side and the developments in consumer engagement at the demand side (Ofgem, 2016). For the market structure, the focus is on the market shares of the suppliers to show the degree of competitive pressure that the suppliers can exert on each other. The prices and profits indicators are used to show the trends across available tariff types and contracts, and the prices that the suppliers offer to different customer groups. In order to indicate the switching and consumer experience, the trends in external switching (between suppliers) and internal switching (within the current supplier) is used to find out the levels of consumer engagement (Ofgem, 2016). Ofgem also used cost pass through to indicate the competitive pressures faced by suppliers. In competitive markets, it is expected that the cost increases will be passed to consumers promptly. The same argument is also expected in reverse. In other words, it is expected that the wholesale cost falls also pass quickly to the end-users. In order to test the asymmetry, the long-run relationship between supplier costs and customer bills were investigated by Ofgem (Ofgem (2011). Due to the lack of sufficient data in the Portuguese market and the fact that the retail rates in Portugal are updated annually by the retailers, we were not able to perform this analysis for the case of Portugal.

The core of this research is a quantitative empirical study, which makes use of publicly available data on Portugal's retail electricity market during the years 2008-2015. Several indicators can be used to show the level of competition in the retail markets and the evolution of the market towards a free competitive market. In this paper, the evolution of the retail prices since the beginning of the liberalization in Portugal's retail electricity market and the relationship between wholesale and retail prices, changes in the market concentration, and switching behavior of customers are studied. The level of retail 
competition in Portugal and its influence on the energy component of the end-users' electricity price is evaluated. In the remainder of this section, the three main aspects of the analysis are explained in more detail.

\subsection{Electricity price}

A variety of different products are offered to customers in liberalized retail markets by electricity suppliers. The variety in the contracts extends beyond the duration and billing (Littlechild, 2006a). Retailers typically offer three types of contracts with different price setting behaviors: (1) fixed-price contracts, (2) variable-price contracts, and (3) spot-price contracts.

The fixed-price contracts are the conventional pricing schemes, with a pre-specified price scheme for the duration of the contract. The variable tariffs contracts are contracts with time-of-use pricing schemes. Different tariffs are offered to customers for different times of the day in these types of contracts. The spot price contracts are linked to the price movements in the wholesale market and reflect the wholesale market price and the distribution tariffs (Mirza and Bergland, 2012). Retailers may avoid frequent changes in the retail rates in harmony with the wholesale price changes due to the cost of notifying the customers for price changes in advance. They also have more tendency to transmit the upward price changes to the customers than the downward price changes. The frequent upward retail price changes may lead to the loss of customers' confidence (Mirza and Bergland, 2012).

Electricity tariff regimes vary between different markets and different customer segments. Electricity tariffs usually include a fixed charge for residential consumers, which is independent of the amount of electricity consumed. This component is typically known as connection charge. The retail rates in this paper refer only to the variable component of electricity tariffs that increases with the amount of consumption (Cai et al., 2013). This component is comprised of different elements, which charge the end-users for energy and supply, network costs, and taxes and levies. In a competitive retail market with a sufficient number of electricity suppliers electricity can be delivered from the wholesale market to the retail end-users at low margins, especially if the customers are expected to switch to a supplier with lower retail rates (Olsen et al., 2006). The main target of the retail market liberalization in the electricity sector is to transfer the changes in the wholesale market price to the retail rates in order to benefit the end users from the market deregulation. The wholesale market prices are used as the departure point to evaluate the impact of liberalization on consumer prices and to assess the cost reflectiveness during the transition period (Karahan and Toptas, 2013).

\subsection{Switching rates}

Customers are classified based on their behavior in a competitive retail market as active or passive. There are several definitions for an active customer. For instance, if active customers are defined as those who have changed their supplier and those who have stayed with the last resort supplier after making inquiries, only the first group is observable. Therefore, the percentage of active customers is usually approximated by the rate of switchers (Defeuilley, 2009), and the minimum requirement is considered as switching to the competitive segment. Passive customers have never switched. They may even pay considerably in excess of the best offers available in the market at a given time (Von Der Fehr and Hansen, 2009).

It is essential to evaluate consumer behavior in order to have a clearer view of the potential of retail market liberalization. The share of active customers can show the development of competitiveness in the retail market.

It is not easy for the end-users to overcome the habit and inertia of remaining at regulated retail rates due to the legacy of monopoly, where the prices were regulated and customers had no options
(Benedettini and Stagnaro, 2015). Furthermore, the persistence of regulated rates in the free market structure reduces the attraction of deregulated offers for the customers. In some markets, such as Italy, Spain, France, Portugal, and Denmark, the regulated retail rates are retained, which is a barrier to the active engagement of customers (Benedettini and Stagnaro, 2015). Switching between the retail companies is promoted by increasing customer awareness about price, contracts, and available options. Informative websites ensure the easy access of customers to these data, simulating costs under contracts with each of the licensed retailers or suggesting contracts that best suit their consumption pattern (Kuleshov et al., 2012).

The customers' insights and perceptions determine when they are likely to terminate the retail contracts and change their suppliers. Customer behaviors depend on the historical changes in the market dynamic. For instance, the electricity consumers in Norway have been historically exposed to pool price volatility due to the dominant share of hydropower units in their generation mix. Accordingly, they are familiar with paying floating rates for electricity and avoid paying a risk premium for fixed-price contracts (Littlechild, 2006a; Mirza and Bergland, 2012).

\subsection{Market concentration}

Competitive markets are identified by the high number of suppliers participating in the market and the low market concentration indices (ACER/CEER, 2015). The Herfindahl-Hirschman index (HHI), expressed in equation (1), shows the degree of market concentration of a particular industry in a geographic region (Chang, 2007). HHI is calculated by adding the sum of the squares of the market shares of the firms in a particular market. HHI is commonly accepted by economists to measure concentration levels. When the whole percentages are used, the HHI ranges from 0 to 10,000 . The lower value is obtained when a very large number of firms exist in the industry and the higher value is for the situation with a single firm in the market (Bhattacharyya, 2011). The market is moderately concentrated when the HHI is between 1500 and 2,500, and highly concentrated when the HHI is above 2500 (Isser, 2015).

$\mathrm{HHI}=\sum_{i=1}^{n}\left(s_{i}\right)^{2}$

Concentration ratios reflect the output of a given number of firms in an industry. Equation (2) shows the calculation of $\mathrm{CR}_{4}$, which represents the sum of the market shares of the four largest firms in a market (ACER/CEER, 2015). $\mathrm{CR}_{4}$ is used in this study to show the extent of market control of the largest electricity suppliers in Portugal and to illustrate the degree to which the retail market is oligopolistic.

$\mathrm{CR}_{4}=\sum_{i=1}^{4} s_{i}$

On the supply side, there are electricity retailers that are only limited to the regional market recognized by the distribution area of the associated distributor. In contrast, there are retailers not confined to the regional markets who compete for market share in other regions (Von Der Fehr and Hansen, 2009). Competitive retail electricity markets usually experience high entry and exit activity of suppliers. The retail electricity providers in the EU countries were interviewed by the Agency for the Cooperation of the Energy Regulators (ACER) about the barriers of entering the developing retail electricity markets at the EU level. The main perceived barriers were the noticeable differences between the regulatory frameworks of the member countries, retail price regulation, high probability of future regulatory developments and low liquidity of the wholesale market (ACER/CEER, 2015). 


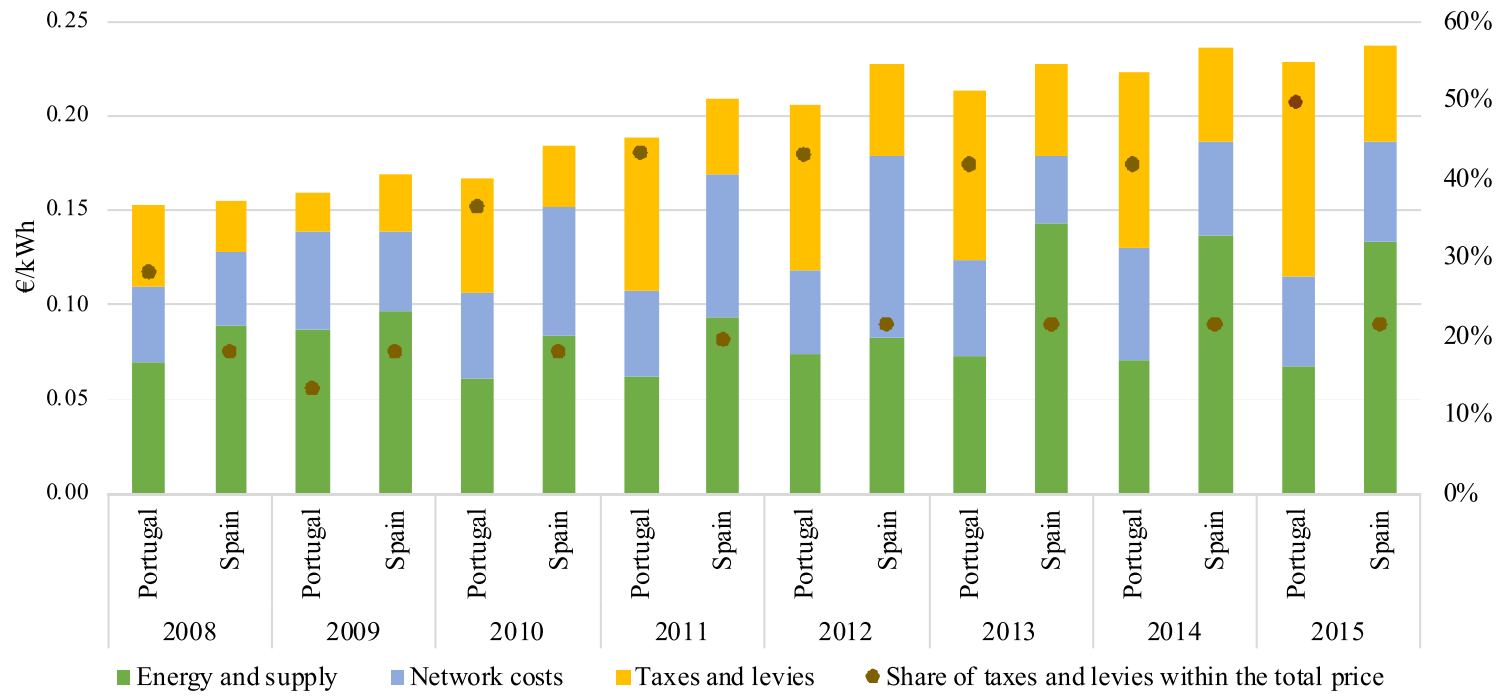

Fig. 1. Average retail electricity prices (€/kWh) for domestic customers in band DC (EUROSTAT, 2016).

\section{Findings and discussion}

\subsection{Electricity price}

Figs. 1 and 2 respectively indicate the average retail electricity prices for residential customers at bands DC $(2500 \mathrm{kWh}<$ Annual consumption $<5000 \mathrm{kWh})$ and DD $(5000 \mathrm{kWh}<$ Annual consumption $<15000 \mathrm{kWh})$ in Portugal and Spain. Band DC represents households with medium standard annual consumption. The retail rates in these figures do not include connection charges and only reflect the energy component of the customers' bills. In Spain, the full customer retail choice has been available since 2003 (London Economics, 2012). The electricity retail prices are taken from the Eurostat official database (EUROSTAT, 2016) and the wholesale market prices are taken from the Iberian Market Operator (OMIE, 2016). The share of taxes and levies (including value-added tax) in the total price of electricity are also shown. The relationship between the changes in the average wholesale and retail prices in Portugal and Spain during the years 2008-2015 can be seen in Figs. 3 and 4. The spot price in Portugal and Spain is usually the same, except for the periods with congestion in the interconnection, which requires market splitting (ERSE, 2016).

In order to provide a measure of the extent to which retail prices have followed the wholesale prices, the potential gains of a typical domestic customer in bands DC and DD in Portugal and Spain from switching to a spot-price contract rather than a fixed-price contract during the year are compared. The MIBEL prices with a fixed mark up of $0.02 € / \mathrm{kWh}$ for the services that the retailers offer are considered as the spot price product (Von Der Fehr and Hansen, 2009). Table 1 shows the expected gains from switching to a spot-price contract. For example, a domestic Portuguese customer in band DC who bought the spot-price product rather than the fixed-price product in 2014 would gain $€ 747$ in that year, or $71.8 \%$ of the annual electricity bill. The potential gain here significantly depends on the amount of fixed markup. Therefore, we have used this calculation for comparison purposes. The purpose is to compare the potential gains of a customer with a similar load profile in Spain and Portugal and also the customers in different bands at the same market.

Figs. 3 and 4 show that the retail rates are generally not following the reductions in the wholesale market price. For instance, despite the reductions in the wholesale rates in 2009, the retail rates increased for Portuguese and Spanish customers in band DC. The customers would have achieved the highest potential gains from switching to the spot price contracts in 2014, in which despite a slight decrease in wholesale market prices, an increase is observed in retail rates (Table 1). In 2014,

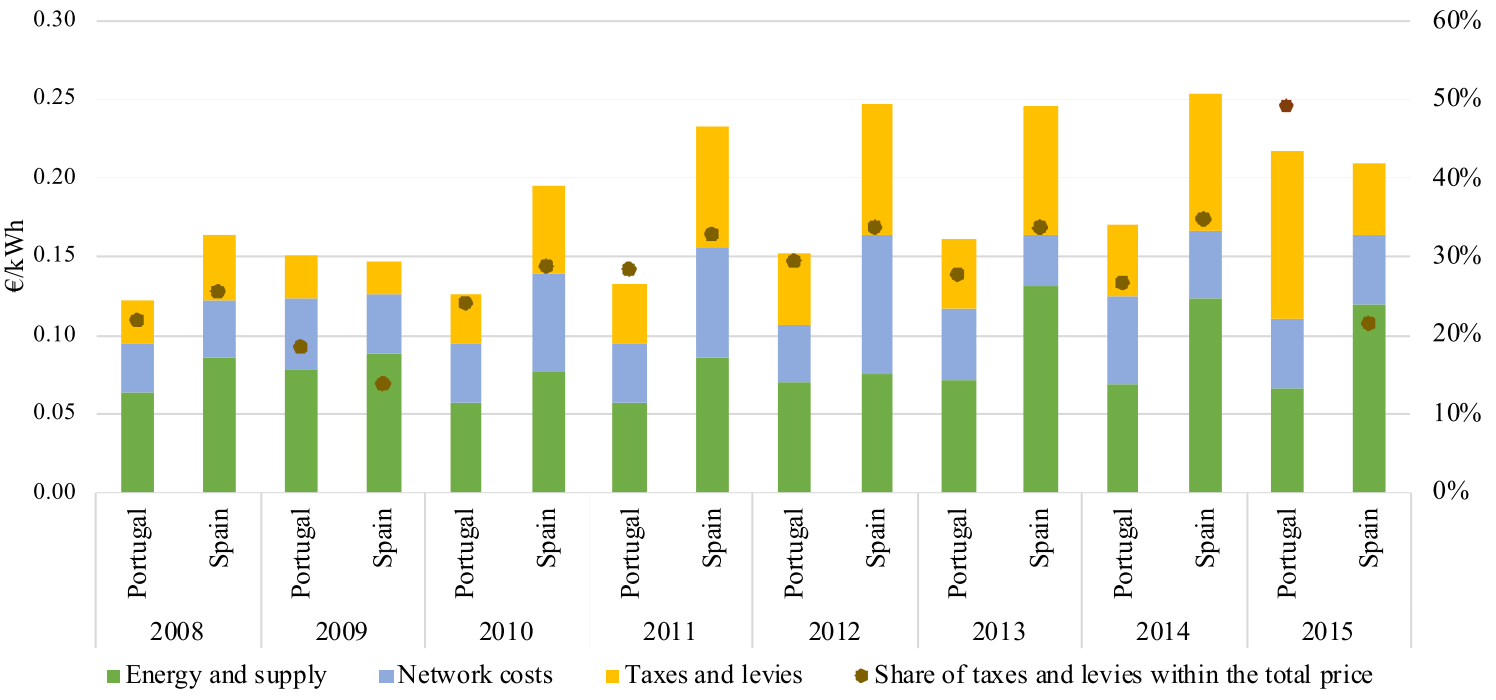

Fig. 2. Average retail electricity prices $(€ / \mathrm{kWh})$ for industrial customers in band DD (EUROSTAT, 2016). 


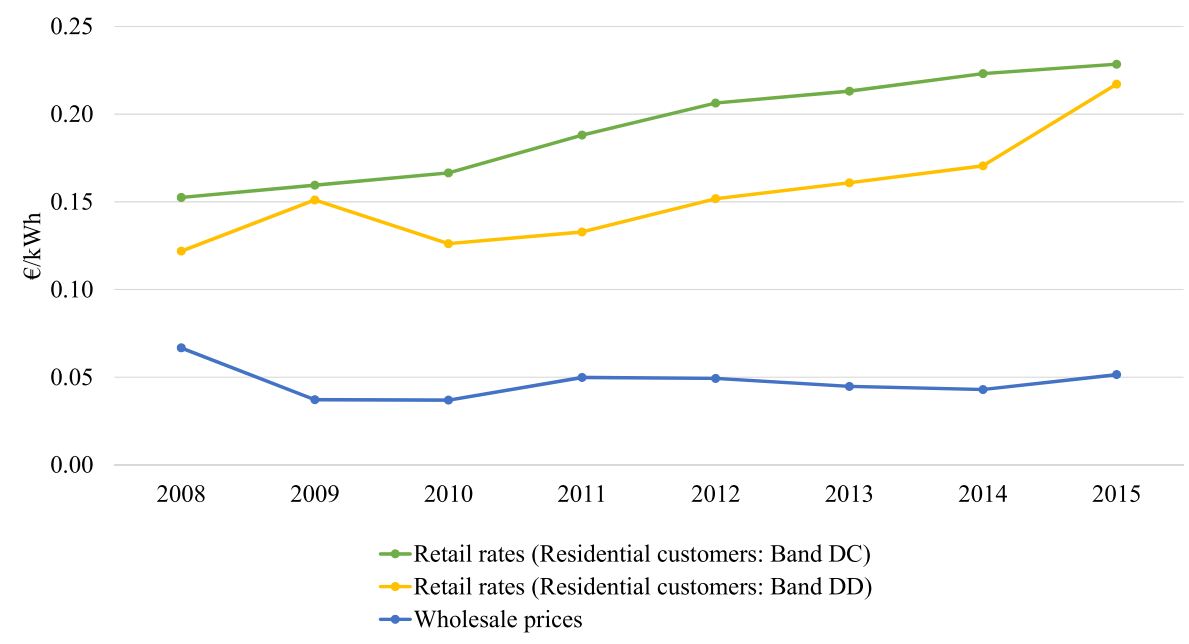

Fig. 3. Average retail and wholesale prices in Portugal.

due to the favorable hydrological conditions and the decline in the coal price, the wholesale market price decreased. The wholesale market price was determined well below the marginal costs of combined-cycle natural thermal plants (ERSE, 2016). Despite this decline, retail rates in Portugal and Spain increased in 2014. Local generation and the interconnection availability factors are the two factors that can significantly impact the wholesale prices. For instance, Portugal and Spain in the first half of 2014 were among the least expensive countries in Europe, but in the third quarter of 2014, they were among the most expensive ones because the generation mix in these countries was pushed towards costlier sources (European Commission, 2014).

Despite the full liberalization of the wholesale market, almost all of electricity generated in Portugal benefits from state guaranteed prices. This situation applies not only to renewable resources or the co-generation units, but also to conventional power plants that have entered into a power purchase agreement (PPA) with the government in the 1990s (Amorim et al., 2013). One reason for the high retail rates in Portugal is the guaranteed remuneration of less efficient thermal plants, designed to operate as base-load power stations, but working only for few hours during a day due to the increasing penetration of wind power generation sources in Portugal.

In the early nineties, when there was a need for new generation capacities to cover the base-load and mid-load electricity consumption in the growing Portuguese market, investments in production were made through long-term PPAs (Finon, 2008). Through these
Table 1

Potential gain of customers in Portugal (PT) and Spain (ES) from switching to a spot-price market.

\begin{tabular}{llllll}
\hline & & \multicolumn{2}{l}{ Domestic customer (band DC) } & Domestic customer (band DD) \\
\cline { 3 - 6 } & & $\begin{array}{l}\text { Potential gain } \\
(€)\end{array}$ & $\begin{array}{l}\text { Potential gain } \\
(\%)\end{array}$ & $\begin{array}{l}\text { Potential gain } \\
(€)\end{array}$ & $\begin{array}{l}\text { Potential gain } \\
(\%)\end{array}$ \\
\hline \multirow{2}{*}{2008} & PT & 314 & $44.2 \%$ & 714 & $47.0 \%$ \\
& ES & 329 & $45.3 \%$ & 328 & $28.9 \%$ \\
2009 & PT & 476 & $64.0 \%$ & 820 & $60.1 \%$ \\
& ES & 518 & $65.9 \%$ & 862 & $61.3 \%$ \\
2010 & PT & 507 & $65.3 \%$ & 1263 & $69.8 \%$ \\
& ES & 594 & $68.8 \%$ & 628 & $53.5 \%$ \\
2011 & PT & 549 & $62.6 \%$ & 1501 & $69.4 \%$ \\
& ES & 646 & $66.3 \%$ & 575 & $46.5 \%$ \\
$\mathbf{2 0 1 2}$ & PT & 644 & $67.0 \%$ & 1662 & $72.2 \%$ \\
& ES & 743 & $70.1 \%$ & 774 & $54.8 \%$ \\
2013 & PT & 688 & $69.3 \%$ & 1670 & $72.8 \%$ \\
& ES & 755 & $71.2 \%$ & 875 & $58.4 \%$ \\
$\mathbf{2 0 1 4}$ & PT & 747 & $71.8 \%$ & 1772 & $75.0 \%$ \\
& ES & 810 & $73.4 \%$ & 997 & $62.8 \%$ \\
$\mathbf{2 0 1 5}$ & PT & 734 & $68.9 \%$ & 1278 & $65.7 \%$ \\
& ES & 774 & $70.0 \%$ & 1355 & $67.0 \%$ \\
\hline
\end{tabular}

agreements, the independent power producers (IPP) invested in new power plants with a sales concession of electricity. They would have essentially received payments to cover their fixed costs (capacity

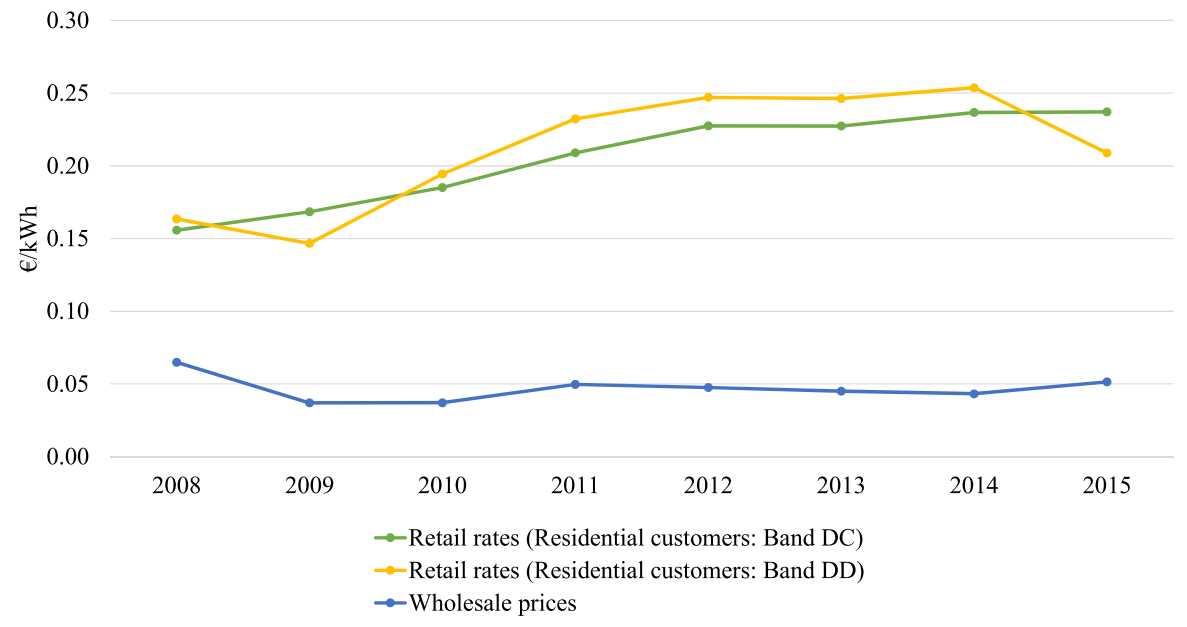

Fig. 4. Average retail and wholesale prices in Spain. 
payments), and payments to cover their variable costs that remunerate the power supply (CEPA, 2004). PPA make the cash flow associated with generation very secure and fully mitigates the market risks (CEPA, 2004). The existence of PPA can make a significant contribution to the difficulties in creating competitive wholesale markets (Amorim et al., 2013). Therefore, all of the PPAs in Portugal except two were replaced with the legislation package of costs with the maintenance of contractual equilibrium (CMEC) in 2007 (Amorim et al., 2013; CEPA, 2004). CMEC regime is a planned system of payments to reduce the PPAs (CEPA, 2004). It is financially equivalent to and has the same economic effect as the existing PPAs (Amorim et al., 2013; CEPA, 2004) in terms of providing a compensation mechanism for recovering the cost of investments made.

Currently, due to the increase in the integration of wind units, the thermal units that were built to operate as a base-load are usually operating as for back-up purposes. Therefore, the installed capacity of the thermal power plants is underused and the fixed costs of investments in these plants have a huge weight on the production costs, which is paid by the end-users.

Another barrier for the effective competition in the retail sector of the Portuguese electricity market is the tariff deficit. It usually occurs when there exist shortfalls of revenue for energy companies as a result of low retail rates, particularly in the regulated component of the price, which does not reflect the actual costs of electricity production (Linden et al., 2014). The existence of tariff deficits, as Portugal has experienced in recent years, prevents the development of effective competition in the retail market by forcing the end-users to cover the tariff deficit. Electricity tariffs must be adjusted so that the utilities can recover their fixed costs. The highest tariff deficit for utility companies in Portugal was experienced in 2013 (Cai et al., 2013). During the economic crisis, customers reduced their consumption; however, the costs incurred by utility companies did not decrease proportionately, especially because of the fixed costs that are usually recovered over decades (Cai et al., 2013).

Over time, retail electricity and natural gas providers can also compete in some applications, such as heating demand in the residential sector. Although the final energy choice is made by the consumers and the builders, the government policies and regulations also have a significant impact on promoting the competition (American Gas Association, 2017). The competition among electricity and gas networks in Portugal can be traced to 1903, when the CRGE finished the construction of a new electric power plant, the Central de Boavista. CRGE then signed a contract with Lisbon's municipal to replace the streetlights that were already powered by gas with electricity (Cardoso de Matos, 2011).

\subsection{Switching rates}

The consumption share of the Portuguese customers in the regulated and the liberalized market is shown in Fig. 5. The increasing trend of switching to the liberalized market for residential customers started in 2013 (Fig. 6), due to the transitory tariffs applied by ERSE.

Portuguese household consumers are perceived as the most active electricity customers in the retail market in Europe during the years 2013-2015. They had the highest switching rates among the EU Member States in these years, despite their relatively low ratings of choices and comparability of offers in the market (ACER/CEER, 2015). Fig. 7 shows the switching rate for several EU countries that have passed 6-11 years since the beginning of the liberalization process in the retail electricity market. In Fig. 7, the switching rate for 2014 and the annual average for years 2008-2013 are shown (ACER/CEER, 2015). The data for 2015 were not yet available for some EU countries at the time of our research. All of the values used here incorporate the switches within the liberalized market. Fig. 7 shows that the Portuguese electricity household consumers have shown an active engagement in switching their retail electricity provider. There is a significant difference between the switching rates in 2014 and the annual average for years 2008-2013. Portugal has the highest difference between the switching rates in 2014 and the annual average of 2008-2013 in Europe. In 2015, a slight decrease is observed in the switching rate of residential customers. In this year, $27 \%$ of electricity consumers switched their electricity supplier. In December 2015, around 34\% of the switches were within the liberalized market.

Switching rates of Spain and Portugal in Fig. 7 also include switching within the same corporate group, but different suppliers. In the case of Portugal it includes switching from the regulated tariffs offered by the last resort supplier (i.e. EDP Serviço Universal) to liberalized market tariffs offered by a different company (i.e. EDP Comercial), which are both within the same corporate. As shown in Fig. 5, the share of consumption in the liberalized market is changing constantly. The high switching rates in 2013-2015 are due to the opening of markets to residential customers.

The limited knowledge of the customers about the potential benefits of switching to a different retailer is a barrier to switching in the retail market (Mukherji, 2012). Generally, the satisfaction of the users from the company is the most important factor to motivate them to switch (Walsh et al., 2005).

Portuguese law has allowed reversibility since January 2018, and the consumers who have switched to the liberalized market can return to the regulated market until 2020. Thus, as long as the transitory tariffs exist, the customers can request to return to the regulated market. The return may happen when the rates offered by the retailers in the liberalized market are higher than the transitory tariffs. The retailers have to present both rates in the bills for customers to compare (Simões, 2018). This law establishes confidence in the market by ensuring the customers that they can return to the familiar system despite the market price contract that they have made (de Suzzoni, 2009).

\subsection{Market concentration}

Despite the developments in the electricity market structure, and high switching rates in Portugal, incumbents were able to maintain a dominant market position in the free market. Fig. 8 shows the changes in market shares of electricity retailers in Portugal since 2008.

On both $\mathrm{HHI}$ and $\mathrm{CR}_{4}$ indices, the retail electricity market in Portugal remains concentrated based on indicative rule-of-thumb thresholds. The market share of the four biggest companies in the liberalized market $\left(\mathrm{CR}_{4}\right)$, the market share of the cross-border retail companies and the HHI are shown in Fig. 9. It shows that the market share of the biggest companies in 2015 is $84.0 \%$, which shows the high concentration of the market. Although the market concentration levels of the suppliers in the market have been reduced significantly since 2008, still the market is highly concentrated. The HHI here is calculated for all consumer types. However, it is expected that the market is even more concentrated for residential customers, as still many of them have stayed in the regulated market.

The interconnection of the Portuguese and Spanish electric systems and the increase in the net transfer capacity have reduced the energy price differences between Portugal and Spain in the wholesale market. Therefore, the financial risks of participating in the Portuguese retail market and competing with the Portugal's incumbent electricity supplier has reduced for the suppliers that operate from Spain (ERSE, 2016). The main cross-border entrants of the Portuguese retail electricity market are Endesa and Iberdrola, which respectively increased their market shares from $2.5 \%$ to $1 \%$ in 2008 to $18.6 \%$ and $16.4 \%$ in 2015.

The level of concentration in the electricity generation segments in Portugal is also high in terms of the installed capacity (ERSE, 2016). EDP owns most of Portugal's power plant generation systems (ERSE, 2016). However, its superior market position is currently being eroded by the regional and cross-border rival companies. The EDP share in the total installed capacity fell by approximately 8\% during 2009-2013 


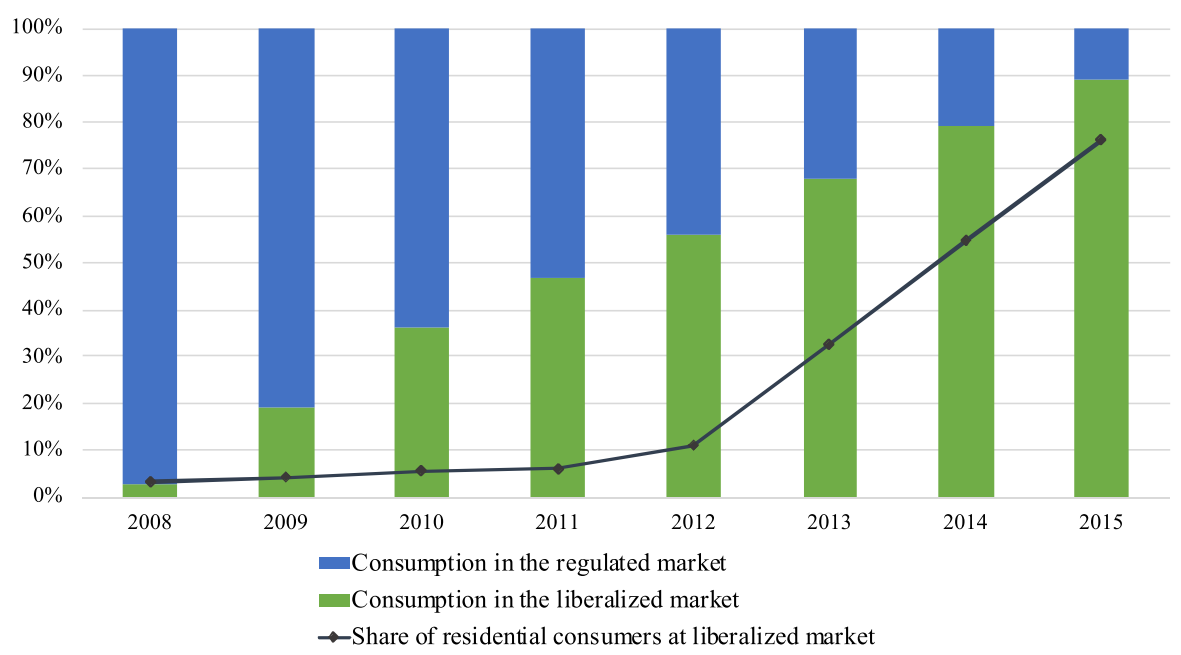

Fig. 5. Consumption share of the Portuguese customers in the regulated and the liberalized market (ERSE, 2016).

(ERSE, 2016).

\section{Conclusions and policy implications}

This empirical analysis focused on the behavior of electricity consumers in Portugal following the liberalization of the retail electricity market.

The motivation underlying the liberalization practices in the retailside of the electricity sector is the possibility of transferring the benefits of a deregulated market to the end-users by providing lower prices and a wide range of contract offers.

The retail competition in Portugal's electricity market is successful in creating new opportunities for consumers. The switching rates of Portuguese customers show the effectiveness of the market. Setting the transitory tariffs during the transition period convinced many end-users to migrate to the liberalized market, despite increasing the gap between the retail rates and the wholesale market prices. The transitory tariffs were used as a procedure to approach the complete removal of the regulated end-user prices. Customers had the chance to search among the available retail electricity providers during the transition period, which was essential to increase the awareness of the users about the benefits of buying electricity in the liberalized market. Without the progressive removal of the regulated rates, customers may fall into the trap of making the wrong decision due to the lack of sufficient information. The results of this study have implications for the policymakers in Portugal who want to efficiently transfer the benefits of market liberalization to end-users. Portuguese governmental policies have gone hand in hand with the EU directives in privatizing statecontrolled electricity companies and liberalizing the retail electricity market. Overall, the integration of the Portuguese and Spanish wholesale electricity markets and, importantly, improving the interconnection capacity between the two countries promoted the entrance of cross-border entrants in the Portuguese retail electricity market. As wholesale market prices in Portugal approach the prices in Spain, the risk of participating in the Portuguese retail market has decreased for the main Spanish electricity suppliers.

Tariff deficits have been recognized as the main reason for the high retail rates in Portugal. For example, in 2012 about $2.5 \%$ of the annual electricity bill of Portuguese customers was to pay the interest of the past five years' tariff deficits. The tariff deficit will be paid by the customers by 2024, assuming no additional increase (Vasconcelos, 2012). The economic crisis has aggravated the tariff deficit in Portugal. The projected demand was higher than the actual demand and tariffs were determined based on those expectations. During the economic crisis, the government also had difficulties in increasing the retail rates in order to compensate for costs. Although the economic crisis is usually recognized as the key reason for the tariff deficit in Portugal, the deficit can also be a consequence of electricity market dysfunction (Linden

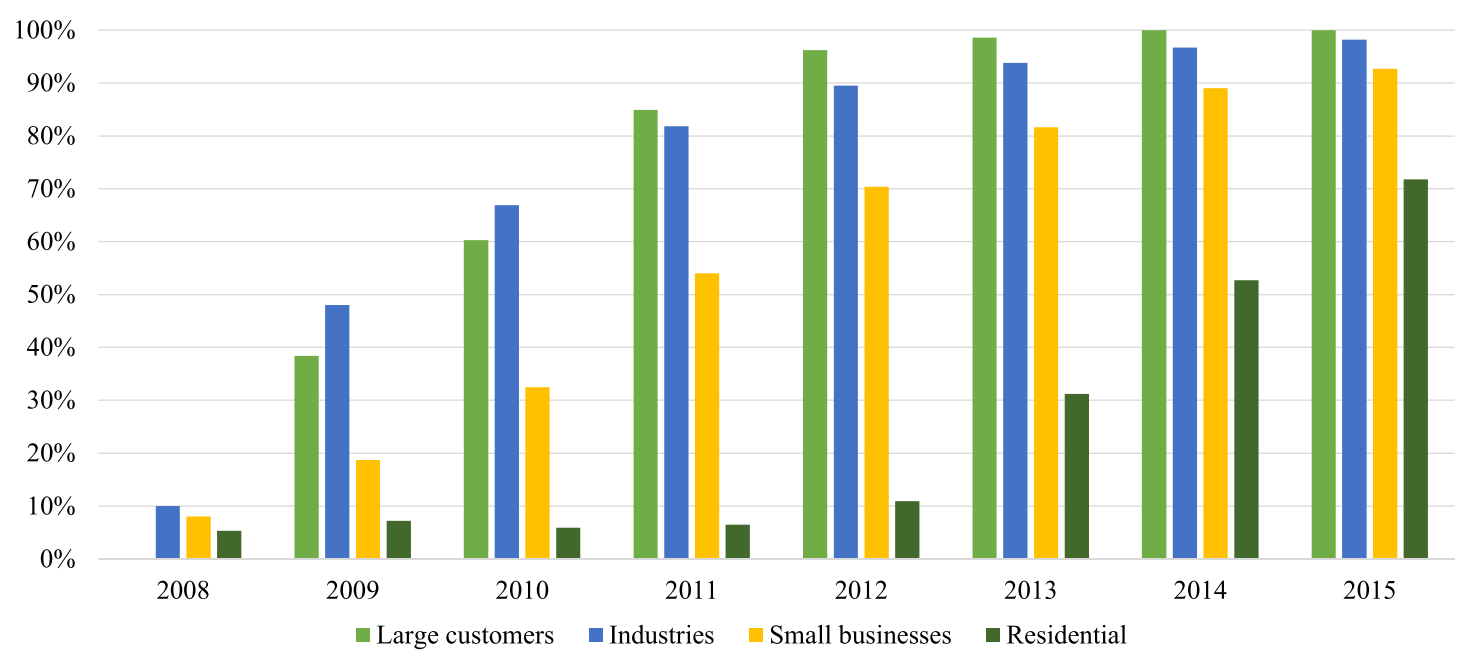

Fig. 6. Changes in the share of different customer segments in the Portugal's liberalized retail electricity market (ERSE, 2016). 


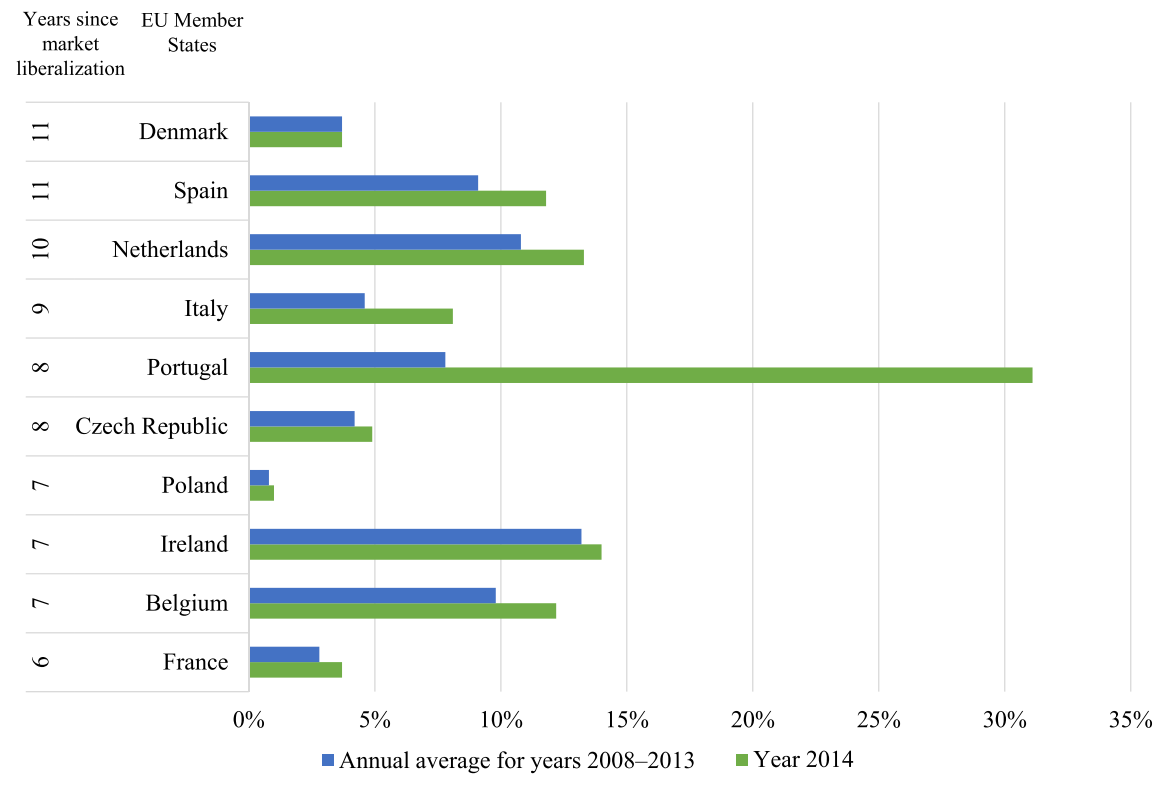

Fig. 7. Switching rates for electricity household consumers (ACER/CEER, 2015).

et al., 2014). It has been widely argued that the government's intervention through regulation and legislation, such as following support policies for the renewable energy units and maintaining the structure of the regulated rates for the retail sector have all contributed to the appearance of increasing tariff deficits.

High taxes and levies in Portugal also add to retail rates. Priceguaranteed production, which applies to PPAs, the CMEC regime, and feed-in tariffs, has imposed high costs on Portuguese customers. Under such agreements, some thermal plants should be remunerated, even when they do not produce electricity.

Besides the reintegration with generation activities, which is an unintended outcome of unbundling in electricity markets, retailers can hedge the risks by investing in physical assets, such as distributed generation units or energy storage systems, or employing demand response programs. Demand response programs can substitute for the activities that require high initial cost or significant changes in the structure of the entity (Finon and Boroumand, 2011). Therefore, another benefit of retail market liberalization is inducing the retailers to adopt new technologies to facilitate the demand-side participation. Demand response is one of the means that small companies cann enter the retailing business and manage their financial risks. However, Portugal has not made any formal decision to roll-out the smart metering throughout the country (CEER, 2013). Moreover, the role of the DSO in implementing the demand response programs for domestic customers with the deployment of smart grids is not well defined (CEER, 2014).

In terms of further research we would like to evaluate the impact of retail market liberalization in Portugal on other aspects of social welfare. In this regard, we plan to study the impact of retail market liberalization on reducing the peak demand. Wholesale market prices normally increase during the peak demand hours, and the retailers must find ways to motivate their customers to consume less during these hours to reduce the risk of financial losses. The technical and economic aspects required for developing new policies and regulatory initiatives to increase the capacity to change electricity usage by end-use customers and the provision of flexibility services by them will be studied in the future works.

\section{Acknowledgement}

The present work was done and funded in the scope of the following

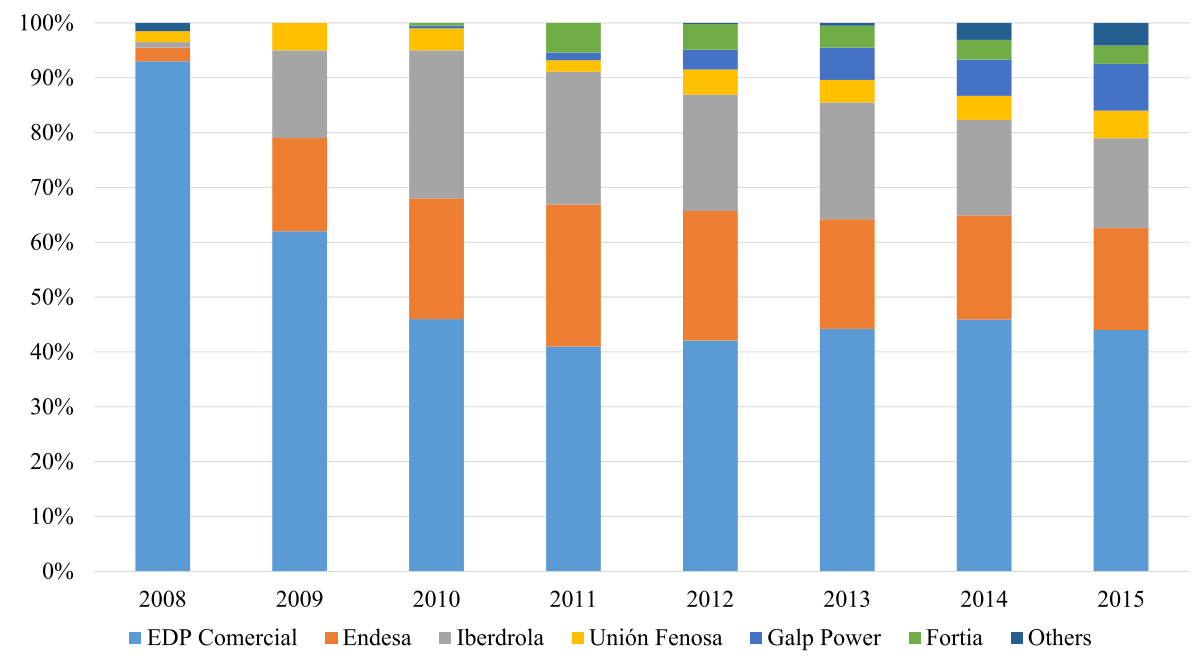

Fig. 8. Market share of electricity retailers in the liberalized market (ERSE, 2016). 


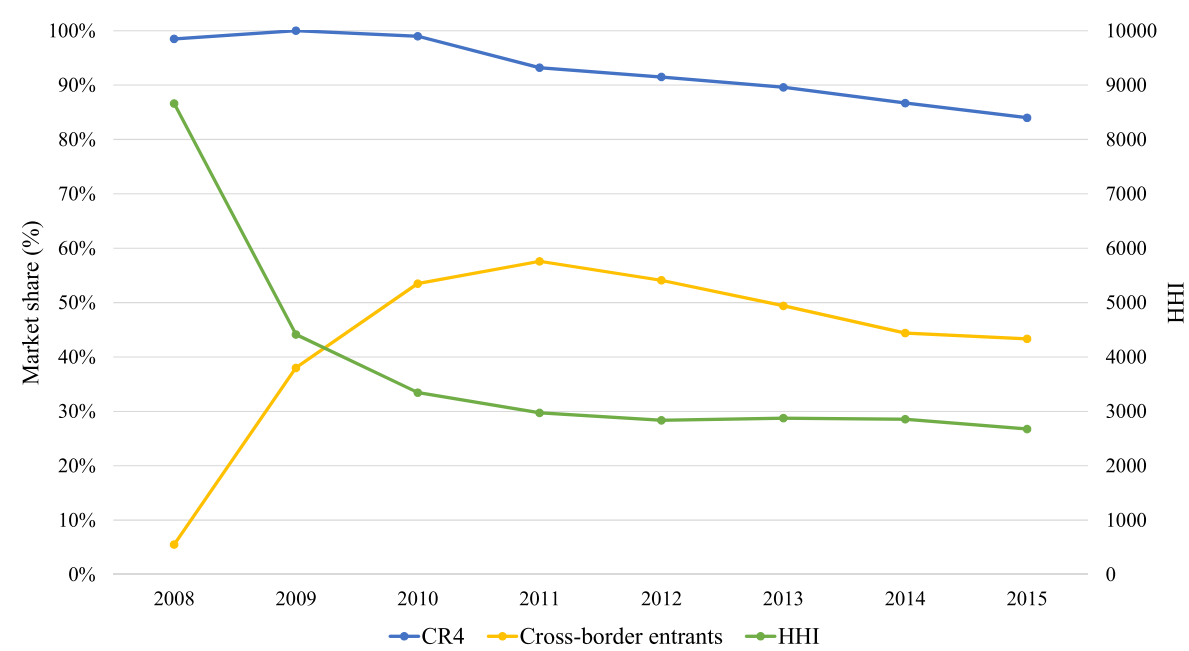

Fig. 9. Market concentration changes and the HHI in Portugal's liberalized retail electricity market (ERSE, 2016).

projects: H2020 DREAM-GO Project (Marie Sklodowska-Curie grant agreement No 641794); EUREKA - ITEA2 Project SEAS with project number 12004; AVIGAE Project (P2020 - 3401); UID/EEA/00760/2013 funded by FEDER Funds through COMPETE program and by National Funds through Fundação para a Ciência e a Tecnologia (FCT); SFRH/ BD/94688/2013 (Mohammd Ali Fotouhi Ghazvini PhD grant).

Rui Castro was supported by national funds through FCT with reference UID/CEC/50021/2013.

\section{Appendix A. Supplementary data}

Supplementary data to this article can be found online at https:// doi.org/10.1016/j.jup.2019.05.005.

\section{References}

ACER/CEER, 2015. Annual report on the results of monitoring the internal electricity and natural gas markets. Technical report. URL: http://www.ceer.eu/portal/page/ portal/EER_HOME/EER_WORKSHOP/CEER-ERGEG\%20EVENTS/CROSSSECTORAL/ACER-CEER_MMR 2014.

American Gas Association, 2017. A Comparison of Energy Use, Operating Costs, and Carbon Dioxide Emissions of Home Appliances. Technical Report.

Amorim, F., Vasconcelos, J., Abreu, I., Silva, P., Martins, V., 2013. How much room for a competitive electricity generation market in Portugal? Renew. Sustain. Energy Rev. $18,103-118$.

Bae, M., Kim, H., Kim, E., Chung, A.Y., Kim, H., Roh, J.H., 2014. Toward electricity retail competition: survey and case study on technical infrastructure for advanced electricity market system. Appl. Energy 133, 252-273.

Benedettini, S., Stagnaro, C., 2015. Failure to liberalise energy retail markets jeopardizes Energy Union. Energy Post. URL: http://www.energypost.eu/failure-liberaliseenergy-retail-markets-jeopardizes-energy-union/.

Bhattacharyya, S.C., 2011. Energy Economics: Concepts, Issues, Markets and Governance. Springer Science \& Business Media.

Bräuninger, D., 2013. Privatisation in the euro area: differing attitudes towards public assets. URL: https://www.dbresearch.com/PROD/DBR_INTERNET_EN-PROD/ PROD0000000000318583/Privatisation + in + the + euro + area\%3A + + Differing + attitud.pdf.

Cai, D.W.H., Adlakha, S., Low, S.H., De Martini, P., Mani Chandy, K., 2013. Impact of residential PV adoption on retail electricity rates. Energy Policy 62, 830-843.

Cardoso de Matos, A.. Urban Gas and Electricity Networks in portugal: Competition and Collaboration (1850-1926) 2011;

CEER, 2013. Status review of regulatory aspects of smart metering. Technical report. URL: http://www.ceer.eu/portal/page/portal/EER_HOME/EER_PUBLICATIONS/ CEER_PAPERS/Customers/2013/7-1_C13-RMF-54-05-Status_Review_of_Regulatory Aspects_of_Smart_Metering_FOR_PUBLICATION.pdf.

CEER, 2014. CEER status review on European regulatory approaches enabling smart grids solutions ("Smart regulation"). Technical report. URL: http://www.ceer.eu/portal/ page/portal/EER_HOME/EER_PUBLICATIONS/CEER_PAPERS/Electricity/Tab3/ C13-EQS-57-04_Regulatory\%20Approaches\%20to\%20Smart\%20Grids_21-Jan-20142.pdf.

CEPA, 2004. Study on Electricity and Gas Markets in Portugal. Technical Report. Cambridge Economic Policy Associates URL: http://www.concorrencia.pt/ SiteCollectionDocuments/Estudos_e_Publicacoes/Energia_e_Combustiveis/05_CEPA_ FinalReport_2004.pdf.
Chang, Y., 2007. The New Electricity Market of Singapore: regulatory framework, market power and competition. Energy Policy 35 (1), 403-412.

Concettini, S., Créti, A., 2013. Liberalization of Electricity Retailing in Europe: Coming Back or Going Forth?

Conejo, A.J., Carrión, M., Morales, J., 2010. Decision Making under Uncertainty in Electricity Markets. International Series in Operations Research and Management Science. Springer US.

Conte, G., Loriot, G., Rouxel, F.X., Tretton, W., 2005. EDP/ENI/GDP: the Commission prohibits a merger between gas and electricity national incumbents. Competition policy newsletter (1), 84-88.

Crispim, J., Braz, J., Castro, R., Esteves, J., 2014. Smart grids in the EU with smart regulation: experiences from the UK, Italy and Portugal. Util. Pol. 31, 85-93.

de Suzzoni, P., 2009. Are regulated prices against the market? European Review of Energy Markets 3 (3), 1-30.

Defeuilley, C., 2009. Retail competition in electricity markets. Energy Policy 37 (2), $377-386$.

EDPSU, 2016. Postponement of extinction period of the transitory rates. URL: http:// www.edpsu.pt/pt/destaques/Pages/adiamentoextincaotarifas.aspx.

ERSE Electricity prices simulator. URL. http://www.erse.pt/pt/electricidade/ simuladores/simuladoresdecomparacaodeprecosnomercado/Paginas/ simuladordecomparacaodeprecosembtnparaportugalcontinental.aspx.

ERSE, 2013. Extinction of regulated tariffs for electricity and natural gas. URL: http:// www.erse.pt/eng/Paginas/extinctiontariffs.aspx.

ERSE, 2016. Annual report to the European commission. URL: http://www.erse.pt/eng/ ue/Paginas/AnnualReporttotheEuropeanCommission.aspx.

EU, 2014. EU energy markets in 2014. Technical report. Publications Office of the European Union, Luxembourg 2014. URL: http://ec.europa.eu/energy/sites/ener/ files/documents/2014/_energy/_market/_en.pdf.

European Commission, 2014. Quarterly report on European electricity markets. Technical report. URL: https://ec.europa.eu/energy/sites/ener/files/documents/quarterlyelectricity_q3_2014_final.pdf .

European Commission, 2016. Smart electricity systems and interoperability. URL: http:// ses.jrc.ec.europa.eu/smart-metering-deployment-european-union.

European Parliament, 2015. Smart electricity grids and meters in the EU member states. Technical report. URL:http://www.europarl.europa.eu/RegData/etudes/BRIE/ 2015/568318/EPRS_BRI\%282015\%29568318_EN.pdf .

EUROSTAT, 2016. Prices of natural gas and electricity. URL: http://ec.europa.eu/ eurostat/web/energy/data/database.

Ferreira, P., Araújo, M., O'Kelly, M., 2007. An overview of the Portuguese electricity market. Energy Policy 35 (3), 1967-1977.

Finon, D., 2008. Investment risk allocation in decentralised electricity markets. the need of long-term contracts and vertical integration. OPEC Energy Review 32 (2), 150-183.

Finon, D., Boroumand, R.H., 2011. Electricity retail competition : from survival strategies to oligopolistic behaviors. In: Colloquium on Regulation of Energy Industries , Economic Center, IFP School (France) and Center for Economic Regulation, City University, Londres. Rueil-Malmaison, France, URL: https://hal-enpc.archivesouvertes.fr/hal-00827297.

Isser, S., 2015. Electricity Restructuring in the United States: Markets and Policy from the 1978 Energy Act to the Present. Cambridge University Press.

Joskow, P., 2008. Lessons learned from electricity market liberalization. Energy J. 29 (2), 9-42.

Karahan, H., Toptas, M., 2013. The effect of power distribution privatization on electricity prices in Turkey: has liberalization served the purpose? Energy Policy 63 (0), 614-621.

Kuleshov, D., Viljainen, S., Annala, S., Gore, O., 2012. Russian electricity sector reform: challenges to retail competition. Util. Pol. 23 (0), 40-49.

Linden, A.J., Kalantzis, F., Maincent, E., Pienkowski, J., 2014. Electricity tariff deficit: temporary or permanent problem in the EU? Technical report; European commission; 
brussels. 10.2765/71426. http://ec.europa.eu/economy_finance/publications/ economic_paper/2014/ecp534_en.htm.

Littlechild, S., 2006a. Competition and contracts in the nordic residential electricity markets. Util. Pol. 14 (3), 135-147.

Littlechild, S., 2006b. Retail Competition in the UK Electricity Sector. Workshops on Retail Competition. (March).

London Economics, 2012. Energy retail markets comparability study: a report for DECC prepared by. Technical report. URL: https://www.gov.uk/government/uploads/ system/uploads/attachment_data/file/200622/London_Economics_-_Energy_Retail_ Markets_Comparability_Study.pdf.

Macauhub News Agency, 2015. Haitong Bank coordinates sale of shares of Portuguese power grid company REN. URL: http://www.macauhub.com.mo/en/2015/11/06 haitong-bank-coordinates-sale-of-shares-of-portuguese-power-grid-company-ren/.

Mirza, F.M., Bergland, O., 2012. Pass-through of wholesale price to the end user retail price in the Norwegian electricity market. Energy Econ. 34 (6), 2003-2012.

Mukherji, S., 2012. A framework for managing customer knowledge in retail industry. IIMB Management Review 24 (2), 95-103. URL: http://www.sciencedirect.com/ science/article/pii/S0970389612000250. https://doi.org/10.1016/j.iimb.2012.02. 003.

Murray, K., Matosin, N., Hefter, E., 2013. Review of Competition in the Retail Electricity and Natural Gas Markets in New South Wales - Report of Interviews with Energy Retailers. (report prepared for the Australian energy market commission). Technical report. http://www.aemc.gov.au/Media/docs/Sapere-Retailer-interview-report7472e182-06ac-480a-a16d-003b7cf2bb71-0.pdf.

Nakajima, T., Hamori, S., 2010. Change in consumer sensitivity to electricity prices in response to retail deregulation: a panel empirical analysis of the residential demand for electricity in the United States. Energy Policy 38 (5), 2470-2476.

OECD, 2013. Portugal: reforming the state to promote growth. Number May. Organisation for Economic Co-operation and Development. URL: http://www.oecd. org/portugal/Portugal-Reforming.theSState.to.Promote.Growth.pdf.

Ofgem, 2016Ofgem,. Retail energy markets in 2016. Technical report. URL: https:// www.ofgem.gov.uk/system/files/docs/2016/08/retail_energy_markets_in_2016.pdf.

Ofgem, 2011. Do energy bills respond faster to rising costs than falling costs ? Technical Report. URL: https://www.ofgem.gov.uk/ofgem-publications/39712/ priceasymmetry.pdf.
Ofgem, 2016. Retail market indicators. URL: https://www.ofgem.gov.uk/data-portal/ retail-market-indicators.

Olsen, O.J., Johnsen, T.A., Lewis, P., 2006. A mixed nordic experience: implementing competitive retail electricity markets for household customers. Electr. J. 19 (9), $37-44$.

OMIE, 2016. URL: http://www.omie.es/files/flash/ResultadosMercado.swf.

Price, C.W., 2005. The effect of liberalizing UK retail energy markets on consumers. Oxf. Rev. Econ. Pol. 21 (1), 128-144.

Roberts, A., 2015. Chinese enterprises pump billions into Portuguese companies. URL: http://www.ft.com/intl/cms/s/0/49d8145c-8489-11e5-8095-ed1a37d1e096.html $\{/ \#\}$ axzz48jG9Iicd.

Shen, D., Yang, Q., 2012. Electricity market regulatory reform and competition-case study of the New Zealand electricity market. In: In: Wu, Y., Sh, X., Kimura, F. (Eds.), Energy Market Integration in East Asia: Theories, Electricity Sector and Subsidies. ERIA Research Project Report 2011-17, vol. 17. pp. 103-139.

Simões, L., 2018. Eletricidade: portugueses podem voltar ao mercado regulado a partir de hoje. O Jornal Económico. URL: https://jornaleconomico.sapo.pt/noticias/ eletricidade-portugueses-podem-voltar-ao-mercado-regulado-a-partir-de-hoje243358.

Swadley, A., Yücel, M., 2011. Did residential electricity rates fall after retail competition? A dynamic panel analysis. Energy Policy 39 (12), 7702-7711.

Tierney, S.F., 2008. ERCOT Texas's Competitive Power Experience: A View from the outside Looking in. Analysis Group URL: http://www.analysisgroup.com/ uploadedFiles/Publishing/Articles/Tierney/_ERCOT/_Texas/_study/_11-08.pdf.

Torres, J.a., October 2011. The InovGrid Project: towards a Smarter Grid. Workshop on Deploying Smart Grids for Customers and a Carbon Neutral Europe 2011.

Vagropoulos, S.I., Bakirtzis, A.G., 2013. Optimal bidding strategy for electric vehicle aggregators in electricity markets. IEEE Trans. Power Syst. 28 (4), 4031-4041.

Vasconcelos, J. What is the electricity tariff deficit? 2012. URL: http://www. jornaldenegocios.pt/opiniao/detalhe/o_que_eacute_o_deacutefice_tarifaacuterio_da_ electricidade.html.

Von Der Fehr, N.H.M., Hansen, P.V.. Electricity Retailing in norway. Available at: SSRN 1346908 2009;.

Walsh, G., Groth, M., Wiedmann, K.P., 2005. An examination of consumers' motives to switch energy suppliers. J. Mark. Manag. 21 (3-4), 421-440. 